\title{
PERCEPATAN PENANGANAN COVID-19 DI BALI: KONTEKS PLURALISME HUKUM ${ }^{1}$
}

\author{
Anak Agung Istri Ari Atu Dewi*, Ni Ketut Supasti Dharmawan, \\ Anak Agung Istri Eka Krisna Yanti, Putri Triari Dwijayanthi \\ Fakultas Hukum, Universitas Udayana \\ Jalan Pulau Bali 1 Denpasar-Bali 80114 \\ ari_atudewi@unud.ac.id
}

\begin{abstract}
Economic conditions in Bali that depend on tourism activities have worsened as a result of Covid-19. This is a lesson for every stakeholder, including Desa Adat in Bali, to jointly handle Covid-19. This writing aims to analyse, examine the implementation of the autonomy of Desa Adat and elaborate the proper synergy model in accelerating the handling of Covid-19. The result shows that the autonomy of Desa Adat in handling Covid-19 was placed in the strategic role of traditional villages in the formation of customary law, namely Pararem, which aims to regulate the life of the Balinese community in accordance with the prevailing law in Indonesia. It shows a synergy model of customary law and national law, which in accordance with the concept of legal pluralism and regulatory compliance.
\end{abstract}

Keywords: Covid-19; Acceleration of Handling; Legal Pluralism; Pararem.

\begin{abstract}
Abstrak
Kondisi perekonomian di Bali yang bergantung pada kegiatan pariwisata menjadi terpuruk sebagai dampak dari Covid-19. Hal ini menjadi pelajaran kepada setiap lapisan termasuk Desa Adat di Bali untuk bersama-sama menangani Covid-19. Penelitian ini bertujuan untuk menganalisis dan mengkaji implementasi otonomi Desa Adat serta mengelaborasi model sinergi yang tepat dalam rangka percepatan penanganan Covid-19. Hasil penelitian menunjukkan bahwa otonomi Desa Adat dalam penanganan Covid-19 ditempatkan pada peran strategis Desa Adat dalam pembentukan aturan hukum adat yaitu Pararem yang bertujuan untuk mengatur kehidupan masyarakat hukum adat Bali sesuai dengan hukum nasional yang berlaku di Indonesia. Hal ini menunjukkan model sinergi berlakunya hukum adat dan hukum nasional sesuai dengan konsep pluralisme hukum dan regulatory compliance.
\end{abstract}

Kata Kunci: Covid-19; Percepatan Penanganan; Pluralisme Hukum; Pararem.

\footnotetext{
${ }^{1}$ Hasil penelitian ini didanai oleh Hibah Unggulan Udayana pada tahun 2021. Penelitian dilaksanakan dalam rangka pemenuhan Tri Dharma Perguruan Tinggi.
} 


\section{A. Pendahuluan}

Sejak 2020, Indonesia berjibaku memerangi penyebaran Covid-19. Indonesia tetap berjibaku untuk memerangi penyebaran Covid-19 hingga hari ini. Keadaan Indonesia sangat mengkhawatirkan, karena Indonesia termasuk sebagai salah satu Negara dengan penyebaran Covid-19 terbanyak di Asia tenggara. Kondisi ini mempengaruhi kondisi Indonesia, termasuk juga Bali.

Bali sebagai daerah tujuan wisata dunia, sangat merasakan dampak dari pandemi ini. Kondisi perkembangan ekonomi di Bali menjadi terpuruk pada titik yang paling rendah. Hal ini memberikan pelajaran bahwa Bali tidak bisa diam dengan melihat kondisi ini. Bali harus bangkit memerangi virus Covid-19 ini.

Di sisi lain, Bali yang terkenal dengan kearifan lokal dan adat-istiadatnya yang terlingkup dalam Desa Adat menjadi berpeluang dalam memerangi virus Covid19 ini. Desa Adat dengan hukum adatnya memiliki daya keberlakuan yang sangat mengikat bagi karma desa adat (masyarakat desa adat) dan hampir semua karma desa adat tersebut patuh dan tunduk pada aturan hukum adatnya.

Desa adat dalam mengelola desa adatnya terikat dengan prinsip otonomi desa adat. Dalam masyarakat hukum adat bali dikenal 3 (tiga) otonomi desa adat yaitu: “1) otonomi desa adat dalam membuat aturan hukum adat; 2) otonomi desa adat dalam menerapkan aturan hukum adat: dan 3) otonomi desa adat dalam menyelesaikan kasus adat" (Putri et al., 2019). Tiga (3) hal ini menjadi penting juga dipahami dalam konteks percepatan penanganan Covid-19 di Bali.

Pemerintah dan Pemerintah Daerah dalam percepatan penanganan Covid-19 ini juga melakukan tindakan-tindakan, seperti mengeluarkan aturan hukum dan kebijakan yang berkenaan dengan percepatan penangananCovid-19. Aturan hukum yang dikeluarkan adalah "UU No. 6 Tahun 2018 tentang Kekarantinaan Kesehatan" yang pada prinsipnya mengatur mengenai tanggung jawab Pemerintah Pusat dan Daerah dalam melindungi kesehatan masyarakat dari penyakit yang berpotensi menimbulkan kedaruratan kesehatan masyarakat. Selanjutnya "Peraturan Pemerintah 21 Tahun 2020 tentang Pembatasan Sosial Berskala Besar (PSBB)" dalam rangka Percepatan Penanganan Covid-19 yang pada prinsipnya mengatur pelaksanaan PSBB sesuai arahan Menteri Kesehatan dan dapat diterapkan oleh Pemerintah Daerah dengan persetujuan dari Menteri Kesehatan.

Peraturan Menteri Kesehatan Nomor 9 Tahun 2020 tentang "Pedoman Pembatasan Sosial Berskala Besar Dalam Rangka Percepatan Penanganan Covid-19" yang pada prinsipnya mengatur mengenai pedoman dan mekanisme penetapan PSBB, Pencatatan, Pelaporan, Pembinaan dan Pengawasan PSBB. Di Tingkat Pemerintah Daerah juga banyak dikeluarkan kebijakan yang mendukung peraturan hukum pemerintah Pusat khususnya berkenaan dengan percepatan Penanganan Covid-19. Pemerintah Provinsi Bali mengeluarkan salah satu kebijakan yaitu "Peraturan Gubernur No. 15 Tahun 2020 tentang Kebijakan Percepatan Penanganan Covid-19 di Provinsi Bali" yang bertujuan mewujudkan percepatan penanganan kesehatan, ekonomi serta penanganan dampak Covid-19 bagi masyarakat dalam bentuk Jaringan Pengamanan Sosial. Ada beberapa Surat Edaran Gubernur Bali yang pada prinsipnya melakukan percepatan penanganan Covid-19 di Provinsi Bali.

Penelitian terdahulu dilakukan pada tahun 2020 oleh Ardika Nurfurqon yang mengkaji mengenai "Analisis Kebijakan Pemerintah Daerah Dalam Penanganan Covid-19: Perspektif Hukum Administrasi" (Nurfurqon, 2020). Dalam penelitian ini, kajian berfokus pada aturan yang dibentuk oleh pemerintah, yaitu pemerintah pusat dan pemerintah daerah untuk menekan penyebaran Covid-19 dalam konteks hukum administrasi. Penelitian ini juga mengkaji mengenai kebijakan daerah Kabupaten Bandung Barat dalam menangani pandemi 
Covid-19. Penelitian serupa juga dilakukan pada tahun 2020 oleh Anak Agung Putu Wiwik Sugiantari dan Lis Julianti yang mengkaji mengenai "Penanggulangan Covid-19 Berbasis Desa Adat Dalam Perspektif Perlindungan Hukum Terhadap Aparatur Desa" (Agung Putu Wiwik S, 2020). Fokus kajian pada penelitian ini adalah mengenai penyelamatan terhadap aparat Desa Adat sebagai pelaksana di lapangan sebagai garda terdepan berkaitan dengan upaya penanganan Covid-19. Penelitian ini juga mengkaji mengenai kebutuhan atas pengaturan yang jelas sebagai bentuk jaminan bagi keamanan aparat Desa Adat dalam melaksanakan tugasnya tersebut.

Berdasarkan paparan tersebut di atas, tampak bahwa terdapat kesamaan pada topik pembahasan yang membahas mengenai upaya penanganan Covid-19 namun, fokus kajian pada penelitian kali ini berbeda. Penelitian ini mengkaji mengenai implementasi otonomi desa dalam rangka percepatan penanganan Covid-19 serta model sinergi yang tepat dalam upaya percepatan penanganan Covid-19 dalam perspektif pluralisme hukum.

Adapun tujuan penelitian ini adalah untuk menganalisis dan mengkaji implementasi otonomi desa dalam rangka percepatan penanganan Covid-19 serta mengelaborasi model sinergi yang tepat dalam percepatan penanganan Covid-19. Tulisan ini akan membahas substansi yang relevan untuk mewujudkan tujuan penulisan. Pertama, disajikan mengenai otonomi desa dalam rangka percepatan penganan Covid19. Kedua, disajikan mengenai model sinergi yang tepat dalam percepatan penanganan Covid-19 dalam perspektif pluralisme hukum.

\section{B. Metode Penelitian}

Penelitian ini merupakan penelitian sosio-legal atau socio-legal research yang mengkaji teks dan konteks. Dalam hal ini, kajian mengenai teks adalah berupa teks hukum yaitu dalam bentuk teks peraturan perundang-undangan dengan dipadukan dengan kajian mengenai konteks yaitu dengan melihat kerjanya hukum dalam masyarakat. Merujuk pada pemikiran Sulistyowati Irianto dapat dipahami bahwa penelitian socio-legal menggunakan kombinasi penelitian doktriner dan nondoktriner (empirik)(Irianto, 2009). Penelitian ini menggunakan pendekatan peraturan perundang-undangan (statutory approach) dan pendekatan konsep (conceptual approach). Penelitian ini juga menggunakan pendekatan bersamaan antara doktriner dan non-doktriner yang saling mendukung dalam sebuah penelitian hukum.

\section{Pembahasan}

\section{Pengaturan Otonomi Desa Adat Dalam Percepatan Penanganan Covid-19}

Konsep Desa Adat sebagaimana tercantum dalam Pasal 1 angka 8 "Peraturan Daerah Provinsi Bali Nomor 4 Tahun 2019 tentang Desa Adat di Bali" (selanjutnya disebut sebagai "Perda Desa Adat") menegaskan bahwa Desa Adat dipahami sebagai "kesatuan masyarakat hukum adat di Bali yang memiliki wilayah, kedudukan, susunan asli, hak-hak tradisional, harta kekayaan sendiri, tradisi, tata krama pergaulan hidup masyarakat secara turun temurun dalam ikatan tempat suci (kahyangan tiga atau kahyangan desa), tugas dan kewenangan serta hak mengatur dan mengurus rumah tangganya sendiri”.

Pemahaman Desa adat sebagai kesatuan Masyarakat Hukum Adat juga terdapat dalam "Putusan Mahkamah Konstitusi Nomor 31/PUU-V/2007 tentang Pengujian UU Nomor 31 Tahun 2007 tentang Pembentukan Kota Tual di Provinsi Maluku terhadap UUD NRI Tahun 1945 yang menetapkan klasifikasi dan kriteria Kesatuan Masyarakat Hukum Adat (selanjutnya KMHA)". KMHA yang tidak lain adalah Desa Adat memenuhi kriteria sebagaimana ditetapkan dalam putusan tersebut yaitu "1) adanya masyarakat yang warganya memiliki perasaan kelompok (infeeling group); 2) adanya pranata 
pemerintahan adat; 3) adanya harta kekayaan atau benda-benda adat; 4) adanya perangkat norma hukum adat dan 5) adanya wilayah tertentu" (Mandasari, 2014).

Mencermati kriteria desa adat dalam Perda Desa Adat dan putusan Mahkamah Konstitusi 31/PUU-V/2007 terdapat kesesuaian yaitu bahwa sebagai Kesatuan Masyarakat Hukum Adat, unsur-unsur yang harus terpenuhi adalah adanya: 1) In feeling group yang dipahami bahwa desa adat sebagai Kesatuan Masyarakat Hukum Adat terikat dengan tradisi, tata krama pergaulan hidup secara turun temurun dalam ikatan khayangan tiga atau khayangan desa; 2) Adanya pranata pemerintahan desa adat dipahami bahwa desa adat dengan otonomi desa adat mempunyai tugas dan kewenangan untuk mengatur rumah tangganya, hal ini juga dipahami bahwa desa adat memiliki tradisi dan tata krama pergaulan baik itu berupa nilai-nilai yang hidup di desa adat yang dapat berfungsi mengendalikan interaksi dan hubungan sosial antar krama desa adat (warga desa adat) sehingga tercapai keteraturan di desa adat; 3) Adanya harta kekayaan atau benda-benda adat dipahami bahwa desa adat memiliki harta kekayaan sendiri yang berfungsi untuk mensejahterakan krama desa adat melalui pengelolaan dan pemanfaatan kekayaan desa adat; 4) Adanya perangkat norma hukum adat, hal ini dipahami bahwa desa adat dapat membentuk dan menerapkan norma hukum adat yang tertuang dalam awig-awig desa adat. Untuk membentuk awig-awig sebagai aturan hukum adat didasarkan pada kewenangan sebagai cerminan otonomi desa adat serta hak-hak tradisional desa adat yang memberi ruang untuk dibentuk perangkat norma hukum adat; dan 5) Adanya wilayah tertentu juga telah berkesesuaian dengan Perda Desa adat yang menentukan bahwa untuk dapat disebut sebagai desa adat maka desa adat harus memiliki wilayah atau palemahan desa adat. Dengan demikian diulangtegaskan bahwa konsep kesatuan masyarakat hukum adat yang terdapat dalam Putusan Mahkamah Konstitusi Nomor
31/PUU-V/2007 dengan Perda desa adat telah sesuai.

Dalam pemahaman desa adat di Bali juga dipahami bahwa dalam pelaksanaan kewenangan Desa Adat dimaknai sebagai otonomi desa adat. Desa Adat dalam konteks otonomi desa adat terdiri atas 3 (tiga) kewenangan yaitu: 1) "Kewenangan desa adat dalam membentuk aturannya sendiri yangdalam hal ini aturan berupa awig-awig, pararem dan keputusan desa adat lainnya"; 2) "Kewenangan desa adat dalam melaksanakan sistem hukum pemerintahan yang tentu saja berdasarkan awig-awig desa adat; dan 3) Menerapkan hukum adat (awig-awig) dalam menyelesaikan permasalahan dan kasus adat yang terjadi di desa adat" (Atu Dewi, 2014).

Berkaitan dengan otonomi Desa Adat sebagaimana telah diatur dalam Pasal 18B ayat (2) UUD NRI Tahun 1945 yang dengan tegas mengatur bahwa "negara mengakui dan menghormati kesatuan-kesatuan masyarakat hukum adat beserta hak-hak tradisionalnya sepanjang masih hidup dan sesuai dengan perkembangan masyarakat dan prinsip Negara Kesatuan Republik Indonesia yang diatur dalam undangundang" (Dwijayanthi, Jones, \& Satyawati, 2017). Pemahaman ini menunjukkan bahwa otonomi desa adat diakui dan dihormati oleh negara sepanjang masih diterapkan dan sesuai dengan perkembangan di Indonesia.

Otonomi desa adat juga dijumpai pada Pasal 1 ayat 1 Undang-Undang Nomor 6 Tahun 2014 Tentang Desa, "Desa adalah desa dan desa adat atau yang disebut dengan nama lain, selanjutnya disebut Desa, adalah kesatuan masyarakat hukum yang memiliki batas wilayah yang berwenang mengatur dan mengurus pemerintahan, kepentingan masyarakat setempat berdasarkan prakarsa masyarakat, hak asal usul, dan/atau hak tradisional yang diakui dan dihormati dalam sistem pemerintahan Negara Kesatuan Republik Indonesia" (Nurcholis, 2014).

Pemahaman ketentuan ini dimaknai bahwa desa merupakan "organisasi komunitas lokal atau desa adat yang mempunyai batas-batas wilayah, dihuni oleh 
sejumlah penduduk, dan mempunyai adatistiadat untuk mengelola dirinya sendiri".(Rahman, Triningsih, \& Kurniawan, 2016) Konsep tersebut dikenal dengan "self governing community". Sebagai "self governing community", desa adat merupakan "bentuk desa asli dan tertua yang memiliki otonomi asli yang dapat mengurus dan mengelola dirinya sendiri serta mengelola harta kekayaan desa adat tanpa ada campur tangan dari negara"(Pramadita, 2017).

Keberadaan desa adat dengan otonomi aslinya juga mendapat pengaturan dalam "Peraturan Daerah Provinsi Bali No. 4 Tahun 2019 tentang Desa Adat di Bali"(Mandira \& Yudha, n.d.). Pada prinsipnya Desa Adat adalah "kesatuan masyarakat hukum adat di Bali yang memiliki wilayah, kedudukan, susunan asli, hak-hak tradisional, harta kekayaan sendiri, tradisi, tata krama pergaulan hidup masyarakat secara turun temurun dalam ikatan tempat suci (kahyangan tiga atau kahyangan desa), tugas dan kewenangan serta hak mengatur dan mengurus rumah tangganya sendiri". Pada konsep desa adat ini, dipahami bahwa desa adat berdasarkan otonominya berhak mengurus rumah tangganya sendiri (Purnama \& Dewi, n.d.), sebagaimana diatur juga dalam konsiderans menimbang, bahwa desa adat dengan otonomi aslinya dapat memberi manfaat yang besar terhadap masyarakat, bangsa dan negara. Secara prinsip otonomi desa adat telah mendapat pengaturan yang jelas dalam peraturan perundang-undangan dengan prinsip pengakuan dan penghormatan oleh negara terhadap otonomi desa adat dalam penyelenggaraan sistem pemerintahan di desa adat.

Dalam konteks percepatan penanganan Covid-19, otonomi desa adat menjadi barometer dalam percepatan penanganan Covid-19 baik dalam tataran pencegahan maupun penanganan Covid-19. Sebagaimana diketahui penyebaran dan tingkat kasus Covid-19 di Bali sangat tinggi, sehingga dalam upaya percepatan penanganan Covid-19 pemerintah dan pemerintah daerah perlu melibatkan desa adat. Dalam peran sertanya, desa adat tentunya dalam melakukan tindakan percepatan penanganan Covid-19 memerlukan aturan yang menjadi payung hukum desa adat untuk bertindak. Dalam percepatan penanganan Covid-19 di Bali, dokumen hukum yang ditetapkan adalah "Keputusan Bersama Gubernur Bali dan Bendesa Agung Majelis Desa Adat Provinsi Bali Nomor: 427/660/PHA/DPMA dan Nomor 003/SKB/MDA-ProvBali/II/2021 tentang Pembentukan Satuan Tugas Gotong Royong Penanganan Covid-19 Berbasis Desa Adat di Bali". Dalam Keputusan bersama ini peran desa adat sangat strategis dalam percepatan penanganan Covid-19 ini.

Peranan strategis desa adat dalam percepatan penanganan Covid-19 ini tentu dengan pelaksanaan otonomi desa adat. Hal ini ditandai dengan pembentukan Pararem Desa Adat di Bali tentang "Pengaturan, Pencegahan dan Pengendalian Gering Agung Covid-19 di Wewidangan Desa Adat". Merujuk pada ketentuan dalam Pasal 1 angka 30 Perda Desa Adat, Pararem adalah aturan atau keputusan Paruman Desa Adat sebagai pelaksanaan Awig-awig atau mengatur hal-hal baru dan/atau menyelesaikan perkara adat/wicara di Desa Adat. Adapun pengertian Paruman Desa Adat adalah suatu lembaga pengambil keputusan tertinggi menyangkut masalah prinsip dan strategis di Desa Adat.

Dalam kaitannya dengan upaya percepatan penanganan Covid-19 yang melanda Indonesia sejak tahun 2020, keberadaan Pararem dapat menjadi pilihan bagi Desa Adat untuk mulai mengatur dan menetapkan aturan yang dianggap perlu mengingat situasi pandemi Covid-19 ini adalah hal yang baru dihadapi oleh Desa Adat di Bali. Penetapan Pararem harus mempertimbangkan hasil diskusi yang dilakukan di tingkat Desa Adat, yaitu melalui Paruman Desa Adat karena Pararem yang dihasilkan dalam konteks percepatan penanganan Covid-19 menyangkut masalah prinsip dan strategis di Desa Adat, mengingat bahwa kemanfaatan, 
keadilan, kekeluargaan, musyawarah merupakan nafas dari adanya Pengaturan Desa Adat.

Sebagaimana diketahui bahwa jumlah desa adat di Bali adalah 1493 desa adat, yang berdasarkan data dari Dinas Pemajuan Masyarakat Adat menunjukkan bahwa 95,65\% atau 1.428 desa adat di Bali telah menyusun Pararem yang bertujuan untuk percepatan penanganan Covid-19. Desa Adat yang belum menyusun Pararem dimaksud adalah sebanyak 55 desa adat atau $4,35 \%$. Untuk lebih jelasnya data disuguhkan dalam tabel 1 .

Berdasarkan data dalam tabel 1 dipahami bahwa peran strategis desa adat dalam percepatan penanganan Covid-19 sebagai peristiwa baru berdasarkan otonomi desa adat telah terbukti dengan telah terbentuknya aturan hukum adat yaitu Pararem tersebut. Dengan telah dibentuknya pararem ini, desa adat melakukan penerapan pararem serta menyelesaikan permasalahan atau kasus yang berkaitan dengan pelanggaran pararem tersebut.

Dengan demikian memahami otonomi desa adat dalam percepatan penanganan Covid-19 ditempatkan pada peran strategis desa adat dalam pembentukan aturan hukum adat yaitu pararem desa adat dalam upaya pencegahan dan pengendalian Covid-19 termasuk pula percepatan penanganan Covid-19 berbasis desa adat. Dengan telah dibentuknya pararem tersebut, dilanjutkan dengan penerapan atau pelaksanaan pararem di wilayah desa adat dengan memberi sanksi adat kepada yang melanggar pararem tersebut. Dengan demikian otonomi desa adat dalam rangka percepatan penanganan Covid-19 dapat dilaksanakan dengan baik di masing-masing desa adat.

Berkaitan dengan pencegahan penyebaran masif Covid-19 di Bali, desa adat dengan pararem desa adat sebagai produk hukum desa adat mengatur krama desa adat dalam upaya pencegahan penyebaran Covid-19, sebagai contoh pada pararem Desa Adat Segeh yang menegaskan bahwa pencegahan dan pengendalian Covid19 di desa adat meliputi perilaku hidup bersih, pembatasan kegiatan berbasis desa adat, satuan tugas gotong royong, penanganan kasus terpapar, ngeneng ngening desa adat, sanksi adat. Berdasarkan pararem Desa Adat Segeh mengatur setiap krama adat, krama tamiu dan tamiu wajib menyediakan tempat cuci tangan di rumah masing-masing, demikian juga operasional pasar tradisional dibatasi dengan jam operasional dan jarak berjualan serta masyarakat yang berjualan di pasar tradisional tetap didata dan diadministrasikan secara tertib. Dalam penanganan kasus yang terpapar dilakukan dengan wajib karantina dan dirawat oleh pihak terkait sesuai dengan prosedur penanganan pasien Covid-19. Hal yang sama juga menjadi objek pengaturan dalam Pararem desa adat lainnya. Oleh karena itu, desa adat yang telah memiliki pararem tentang Pencegahan dan Pengendalian Gering Agung Covid-19 di Wewidangan Desa Adat cenderung mengalami kasus terkonfirmasi Covid-19 yang menurun. Hal ini disebabkan adanya ketentuan mengikat krama desa, krama tamiu dan tamiu yang tinggal di wewidangan desa adat dan apabila ada pelanggaran akan dikenakan sanksi adat.

Tabel 1.

Pararem Desa Adat tentang Pengaturan, Pencegahan dan Pengendalian Gering Agung Covid-19 di Wewidangan Desa Adat

\begin{tabular}{lccc}
\hline Kabupaten & $\begin{array}{l}\text { Jumlah } \\
\text { Desa Adat }\end{array}$ & Sudah & Belum \\
\hline Buleleng & 170 & 170 & 0 \\
Jembrana & 64 & 64 & 0 \\
Bangli & 168 & 153 & 15 \\
Badung & 122 & 97 & 25 \\
Gianyar & 273 & 272 & 1 \\
Tabanan & 349 & 330 & 9 \\
Karangasem & 190 & 189 & 1 \\
Klungkung & 122 & 118 & 4 \\
Kota & 35 & 35 & 0 \\
Denpasar & & $\mathbf{1 4 2 8}$ & $\mathbf{5 5}$ \\
Total & $\mathbf{1 4 9 3}$ &
\end{tabular}

Sumber: Dinas Pemajuan Masyarakat Adat Provinsi Bali 
Aspek Pencegahan dan pengendalian Covid-19 di desa adat yang belum memiliki pararem menunjukan belum terlaksananya secara optimal. Tujuan dibuatnya pararem ini juga sebagai arah dan pedoman prajuru desa adat dan satuan gugus tugas gotong royong dalam pelaksanaan pencegahan Covid-19. Oleh karena itu perlu dilakukan upaya bagi desa adat yang belum memiliki pararem desa adat tentang pencegahan dan pengendalian penyebaran Covid-19 untuk segera membentuk pararem sebagai landasan hukum untuk melaksanakan tindakan hukum di desa adat. Dengan demikian dapat diasumsikan bahwa dengan dibentuknya pararem di masing-masing desa adat dan penerapan pararem dilaksanakan secara optimal maka pencegahan dan pengendalian penyebaran masif Covid-19 dapat dibendung atau dikendalikan.

Penerapan pararem desa adat dalam aspek pencegahan dan pengendalian Covid19 di Bali menjadi pilihan model unik, mengingat hal ini akan lebih efektif diterapkan pada masyarakat Bali yang memang sangat taat dan patuh terhadap aturan hukum adat yang diterapkan oleh desa adat. Pencegahan dan pengendalian Covid-19 berbasis otonomi desa adat dengan mengoptimalkan penerapan pararem di masing-masing desa adat, niscaya penyebaran masif Covid-19 dapat terkendali, sehingga kesejahteraan desa adat dapat terwujud.

\section{Model Sinergi Percepatan Penanganan Covid-19 Dalam Perspektif Pluralisme Hukum}

Sinergi antara Pemerintah daerah dengan desa adat dalam percepatan penanganan Covid-19 dibalut dalam kerangka pluralisme hukum. Pluralisme hukum dipahami sebagai keberlakuan hukum lebih dari satu sistem hukum. Pemahaman mengenai keberlakuan hukum di Indonesia, tampak jelas, selain berlaku hukum negara yang oleh Nurjaya (Nurjaya \& SH, 2004) disebut sebagai "state law", juga berlaku hukum rakyat (folklaw) dan hukum agama yang sering disebut religious law. Pluralisme hukum adalah suatu kondisi dimana terdapat sinergi antara satu sistem atau institusi hukum secara bersama-sama dalam aktivitas dan hubungan tertentu. (Franz von benda Beckman, Keebet Von Benda Beckmann, 2001) Sinergi dalam pluralisme hukum sebenarnya sangat kental dengan keberadaan hukum di Indonesia khususnya di Bali yaitu dengan diberlakukannya hukum adat dalam kehidupan masyarakat.

Memahami konsep pluralisme hukum, Griffiths dikenal adanya dua macam pluralism hukum yaitu“"weak legal pluralism dan strong legal pluralism"(Griffiths, 1986). "Weak Legal Pluralism" atau dikenal pluralisme hukum Negara merupakan bentuk lain dari pada sentralisme hukum yang menempatkan hukum Negara dalam posisi superior sementara hukum-hukum lainnya berada dalam satu hierarki di bawah hukum negara. "strong legal pluralism" menempatkan semua sistem hukum yang ada pada kedudukan yang sama dalam masyarakat, sehingga tidak terdapat suatu hierarki yang menunjukkan adanya jenjang norma (Irianto, 2003).

Pemikiran Sally Falk Moore yaitu konsep teori"the semi-autonomous social field yang menyatakan Law is the self regulation of a semi-autonomous social field'.(Moore, 1973) Merujuk pada pemikiran Sally Falk Moore dapat dipahami bahwa sistem hukum adat berada dalam suatu sistem hukum negara (Dewi, Pramana, \& Tanaya, n.d.). Dalam kerangka pluralisme hukum dikenal dengan pluralisme hukum negara. Pluralisme hukum negara dapat dipahami bahwa hukum negara memberikan pengakuan pada kemajemukan hukum. Ini menandakan hukum adat berada dalam kerangka pluralisme hukum negara.

Senada dengan pemikiran Griffiths dan Sally Falk Moore, Werner Menski menegaskan 3 (tiga) unsur utama dalam konsep segitiga pluralisme (triangle pluralism) yaitu "unsur masyarakat, unsur negara dan unsur nilai dan etika yang saling berinteraksi dan saling mempengaruhi" 
(Pasaribu \& Sirait, 2018). Ketiga unsur tersebut saling bersinergi dengan sifat pluralistis.

Memahami konsep pluralisme hukum dalam konteks percepatan penanganan Covid-19 dilihat dari aspek regulasi atau aspek pengaturan. Aspek pengaturan dalam pemahaman pluralisme menempatkan pengaturan percepatan penanganan Covid19 dalam hukum negara dan hukum adat. Dalam aspek pengaturan dalam hukum negara berkaitan dengan percepatan penanganan Covid-19 diuraikan dalam tabel 2. Selanjutnya produk hukum daerah Provinsi Bali mengenai percepatan penanganan Covid-19 dituangkan dalam tabel 3 .

Berdasarkan pengaturan baik secara Nasional maupun pengaturan di Daerah Provinsi Bali yang berkenaan dengan Percepatan Penanganan Covid-19, tampak ada sinergi antara aturan hukum Pusat (Pemerintah Pusat) dengan Peraturan Hukum di tingkat Daerah (Provinsi Bali) yang pada prinsipnya adalah Percepatan penanganan Covid-19. Di sisi lain pengaturan yang tidak kalah penting dijelaskan adalah pengaturan berdasarkan hukum adat khususnya hukum adat Bali yang dituangkan dalam bentuk "awig-awig" dan "pararem"(Sudantra, 2014). Pengaturan hukum adat Bali perlu mengacu pada ketentuan peraturan perundang-undangan sebagai implementasi pluralisme hukum (Yusa\& Dharmawan, 2019).

Pengaturan percepatan penanganan Covid-19 dalam perspektif hukum adat dapat dilihat dari pararem yang dibuat oleh masing-masing Desa Adat di Bali (Yulianingsih \& CP, 2018). Pengaturan percepatan penanganan Covid-19 yang dituangkan dalam pararem senada dengan teori hukum progresif sesuai pemikiran Satjipto Rahardjo. Merujuk pada karakter hukum progresif dapat dipahami bahwa hukum tidak bersifat stagnan, melainkan mengalir sesuai dengan kebutuhan manusia dan berusaha memberikan perhatian terhadap keadilan dalam masyarakat demi tercapainya kesejahteraan umat manusia
(Marilang, 2017). Merujuk pada pemikiran Satjipto Rahardjo, suatu peraturan harus dikaji dalam kontekstualisasinya dengan realitas ruang dan waktu (Mukminto\& Marwan, 2019). Sehingga, hukum tidak hanya berupa peraturan tetapi merupakan suatu kesatuan ide, kultur dan cita-cita yang ingin diwujudkan demi kesejahteraan umat manusia (Mukminto\& Marwan, 2019).

Senada dengan hal tersebut, sebagai upaya untuk percepatan penanganan Covid19 di Bali, Desa Adat melalui Pararem dapat menerapkan sanksi adat bagi masyarakat di Desa Adat. Hal ini senada dengan teori Regulatory Compliance yang dikemukakan oleh Sutinen dan Kuperan (Sarawa \& Mas' ud, 2020). Merujuk pada teori ini, kepatuhan masyarakat pada hukum dipengaruhi oleh berbagai faktor, antara lain faktor psikologi dan faktor sosiologi dari masyarakat itu sendiri (Sarawa \& Mas' ud, 2020). Selain itu, teori ini juga memberikan penekanan pada kewajiban moral dari masyarakat yang mempengaruhi kepatuhan atas suatu keputusan (Sarawa \& Mas' ud, 2020). Hal ini berlaku secara umum dalam pelaksanaan aturan hukum, tidak terkecuali Pararem. Melihat konsep Pararem yang diatur dalam Perda Desa Adat, sejatinya keberadaan Pararem sebagai perwujudan hukum adat lebih dapat diterima dan dipatuhi oleh masyarakat adat. Mengingat proses pembuatan dan penetapan suatu Pararem didasari oleh adanya Paruman Desa Adat yang melibatkan masyarakat Desa Adat dalam pengambilan suatu keputusan, termasuk juga keputusan untuk menanggulangi penyebaran Covid-19 di Desa Adat.

Pembentukan Pararem khususnya mengenai "Pengaturan Pencegahan dan Pengendalian Gering Agung Covid-19 di Wewidangan Desa Adat" merupakan sinergi antara hukum nasional dan hukum adat sebagai implementasi dari "teori Hukum Progresif", konsep "Pluralisme Hukum" dan Regulatory Compliance. Pada prinsipnya, model pengaturan tersebut mengatur mengenai pencegahan, menghambat dan memutus penyebaran Covid-19 di 
Wewidangan Desa adat dengan melibatkan Desa Adat termasuk prajuru, Satgas Gotong Royong, Krama Tamiu dan Tamiu dengan menyesuaikan pada kondisi masyarakat
Desa Adat serta memfokuskan pengaturan Pararem sesuai dengan kebutuhan dari masing-masing Desa Adat.

Tabel 2.

Hukum Nasional dalam Percepatan Penanganan Covid-19

\begin{tabular}{|c|c|c|}
\hline No & Peraturan & Tentang \\
\hline 1. & UU 6/2018 & "Kekarantinaan Kesehatan" \\
\hline 2 & PP 21/2020 & $\begin{array}{l}\text { "Pembatasan Sosial Berskala Besar } \\
\text { (PSBB dalam Rangka Percepatan } \\
\text { Penanganan Corona Virus Disease } \\
2019 \text { (Covid-19)" }\end{array}$ \\
\hline 3 & $\begin{array}{l}\text { Perpu } \\
1 / 2020\end{array}$ & $\begin{array}{l}\text { "Kebijakan Keuangan Negara dan } \\
\text { Stabilitas Sistem Keuangan untuk } \\
\text { Penanganan Pandemi } \\
\text { CoronaVirusDisease } 2019 \text { (Covid- } \\
\text { 19) dan/atau dalam rangka } \\
\text { menghadapi ancaman yang } \\
\text { membahayakan perekonomian } \\
\text { nasional dan/atau stabilitas sistem } \\
\text { keuangan" }\end{array}$ \\
\hline 4. & $\begin{array}{l}\text { Keputusan } \\
\text { Presiden } \\
7 / 2020\end{array}$ & $\begin{array}{l}\text { "Gugus Tugas Percepatan } \\
\text { Penanganan CoranaVirusDisease } \\
\text { 2019(Covid-19)" }\end{array}$ \\
\hline 5 & $\begin{array}{l}\text { Keputusan } \\
\text { Presiden } \\
9 / 2020\end{array}$ & $\begin{array}{l}\text { "Perubahan Atas Keputusan } \\
\text { Presiden Nomor 7/2020 tentang } \\
\text { Gugus Tugas Percepatan } \\
\text { Penanganan CoronaVirusDisease } \\
2019 \text { (Covid-19)" }\end{array}$ \\
\hline
\end{tabular}

6 Keputusan "Penetapan Kedaruratan Kesehatan Presiden 11 Masyarakat Corona Virus Disease" $/ 2020$

$7 \quad$ Instruksi

Presiden

$4 / 2020$

8. Peraturan

Menteri

Kesehatan

9/2020

9. Surat

Edaran

Mendikbud

$3 / 2020$
Anotasi

Terdapat tanggung jawab Pemerintah Pusat dan Daerah dalam usaha melindungi kesehatan masyarakat dari penyakit yang berpotensi menimbulkan keadaan darurat kesehatan masyarakat melalui penyelenggaraan karantina kesehatan.

Pengaturan PSBB yang ditetapkan oleh Menteri Kesehatan dan dapat dilakukan oleh Pemerintah Daerah dengan persetujuan Menteri Kesehatan.

Mengatur pelaksanaan APBN dalam rangka penanganan pandemi Covid-19 dan menghadapi ancaman yang membahayakan perekonomian nasional dan/atau stabilitas sistem keuangan.

Mengatur "pembentukan Gugus Tugas Percepatan Penanganan Covid-19.”

Mengatur "Perubahan Atas Keputusan Presiden 7 Tahun 2020 tentang Gugus Tugas Percepatan Penanganan Corona Virus Disease 2019 (Covid19), antara lain susunan keanggotaan Gugus Tugas Percepatan Penanganan Covid.19 dan pendanaan yang diperlukan untuk kegiatan gugus tugas."

Menetapkan Covid-19 sebagai jenis penyakit yang menimbulkandan menetapkan kedaruratan kesehatan masyarakat. PenanggulanganCovid-19 wajib dilakukan sesuai dengan peraturan perundang-undangan.

Mengatur langkah-langkah cepat, tepat, fokus, terpadu dan sinergi antar Kementerian/ Lembaga dan Pemerintah Daerah untuk melakukan refocusing kegiatan relokasi anggaran serta pengadaan barang dan jasa dalam rangka percepatan penanganan Covid-19.

Mengatur tentang pedoman mekanisme penetapan PSBB pelaksanaan PSBB, Pencatatan dan Pelaporan, serta Pembinaan dan Pengawasan PSBB.

Imbauan kepada para Kadisdik Provinsi, Kabupaten/Kota, Kepala Lembaga Layanan Pendidikan Tinggi, Pimpinan Perguruan Tinggi, serta Kepala Sekolah agar memedomani Pencegahan Covid-19 di satuan pendidikan berdasarkan tingkat risiko penyebaran.

Sumber: Elaborasi dari Peraturan hukum berkaitan dengan percepatan Penanganan Covid-19. 
Tabel 3.

Produk Hukum Daerah Provinsi Bali dalam Percepatan Penanganan Covid-19

\begin{tabular}{|c|c|c|c|}
\hline No & Peraturan & Tentang & Anotasi \\
\hline 1. & Pergub 15 Tahun 2020 & $\begin{array}{l}\text { "Paket Kebijakan Percepatan } \\
\text { Penanganan Corona Virus } \\
\text { Disease } 2019 \text { (Covid-19) di } \\
\text { Provinsi Bali" }\end{array}$ & $\begin{array}{l}\text { Aturan ini dibentuk untuk lebih } \\
\text { percepatan penanganan kesehatan, } \\
\text { percepatan penanganan dampak Covid- } \\
19 \text { terhadap perekonomian dan } \\
\text { penanganan dampak Covid-19 terhadap } \\
\text { masyarakat dalam bentuk Jaring } \\
\text { Pengaman Sosial (JPS). }\end{array}$ \\
\hline 2 & Pergub 23 Tahun 2020 & $\begin{array}{l}\text { "Pemberian Bantuan Jaring } \\
\text { Pengaman Sosial Kepada } \\
\text { Lembaga/Organisasi Dalam } \\
\text { Rangka Percepatan } \\
\text { Penanganan Corona Virus } \\
\text { Disease } 2019 \text { (Covid-19) Di } \\
\text { Provinsi Bali" }\end{array}$ & $\begin{array}{l}\text { Diatur mengenai realokasi Anggaran; } \\
\text { penanganan dampak COVID-19 } \\
\text { terhadap Lembaga/Organisasi dalam } \\
\text { bentuk Jaring Pengaman Sosial (JPS); } \\
\text { dan kriteria, mekanisme, dan } \\
\text { pertanggungjawaban, sehingga } \\
\text { memberikan arah, landasan, dan } \\
\text { kepastian hukum bagi Pemerintah } \\
\text { Provinsi dan pemangku kepentingan } \\
\text { dalam pemberian Bantuan Jaring } \\
\text { Pengaman Kepada } \\
\text { Lembaga/Organisasi Dalam Rangka } \\
\text { Percepatan Penanganan Corona Virus } \\
\text { Disease 2019 (Covid-19) di Provinsi } \\
\text { Bali. }\end{array}$ \\
\hline 3. & Pergub 46 Tahun 2020 & $\begin{array}{l}\text { "Penerapan Disiplin Dan } \\
\text { Penegakan Hukum Protokol } \\
\text { Kesehatan Sebagai Upaya } \\
\text { Pencegahan Dan Pengendalian } \\
\text { Corona Virus Disease } 2019 \\
\text { Dalam Tatanan Kehidupan Era } \\
\text { Baru" }\end{array}$ & $\begin{array}{l}\text { Dalam aturan ini ditegaskan bahwa } \\
\text { diperlukan peningkatan partisipasi aktif } \\
\text { Krama Bali dan pemangku kepentingan } \\
\text { dalam mencegah penularan dan } \\
\text { penyebaran COVID-19 serta upaya } \\
\text { pemulihan berbagai aspek kehidupan } \\
\text { sosial ekonomi secara produktif dan } \\
\text { aman untuk mengurangi dampak } \\
\text { psikologis warga masyarakat akibat } \\
\text { pandemi COVID-19 }\end{array}$ \\
\hline
\end{tabular}

4. Surat Edaran Gubernur Bali "Pelaksanaan Kegiatan 01 Tahun $2021 \quad$ Masyarakat Dalam Tatanan

Kewajiban untuk melaksanakan protokol Kehidupan Era Baru Di Provinsi Bali” kesehatan bagi seluruh pihak sesuai standard kesehatan. Apabila ketentuan ditas dilanggar maka akan dikenakan sanksi sesuai dengan "Pergub 46 Tahun 2020" dan Peraturan perundangundangan lainnya.

5. Surat Edaran Gubernur Bali "Pemberlakuan Pembatasan 03 Tahun 2021 Kegiatan Masyarakat Berbasis Desa/Kelurahan Dalam Tatanan Kehidupan Era Baru Di Provinsi Bali”

Pemberlakuan Pembatasan Kegiatan Masyarakat Berbasis Desa/Kelurahan se-Bali ditentukan berdasarkan pada zonasi Covid-19 tingkat desa/kelurahan di Kabupaten/Kota yang ditetapkan oleh Bupati/Walikota se-Bali.

6. Keputusan Bersama "Pembentukan Satuan Tugas

Pada prinsipnya bahwa dalam Gubernur Bali dan Majelis Gotong Royong Pencegahan percepatan penanganan Covid-19 di Desa Adat Provinsi Bali Covid-19 Berbasis Desa Adat Nomor: $472 /$ Di Bali" Bali, setiap Desa Adat di Bali membentuk SATGAS GOTONG ROYONG Pencegahan Covid-19 1571/PPDA/DPMA Nomor: Berbasis Desa Adat. 
Berdasarkan partisipasi aktif desa adat dalam upaya percepatan penanganan Covid19 di Bali memberi gambaran dan pemahaman bahwa dalam percepatan penanganan Covid-19 sinergi antara hukum negara dan hukum adat yang terbalut dalam kerangka Pluralisme hukum sangat diperlukan dan mempercepat penanganan Covid-19 di Bali. Hal ini di tandai bahwa semua aspek bergerak baik itu Pemerintah Daerah dan Desa adat di Bali dengan tujuan untuk percepatan penanganan Covid-19 di Bali. Sehingga, sinergi antara hukum nasional dan hukum adat sangat dibutuhkan berkaitan dengan upaya percepatan penanganan Covid-19 dapat terwujud dan masyarakat kembali menjalani tatanan kehidupan normal era baru.

\section{Simpulan dan Saran}

Strategi percepatan penanganan Covid19 dalam perpektif pluralisme hukum sangat diperlukan. Sinergi antara hukum adat dan hukum nasional dalam percepatan penanganan Covid-19 ditunjukan dengan penggunaan berbarengan sistem hukum yang berbeda untuk tujuan penanggulangan Covid-19. Penggunaan hukum adat dalam percepatan penanganan Covid 19 adalah dengan dibuatnya pararem desa adat dalam upaya Pencegahan dan Pengendalian Gering Agung Covid-19 di Wewidangan Desa Adat. Percepatan penanganan Covid-19 berbasis desa adat dan hukum nasional berdampak pada taatnya krama desa adat (masyarakat hukum adat) dan masyarakat secara umum terhadap aturan hukum baik itu pararem dan hukum nasional. Dengan demikian model sinergi hukum adat dan hukum nasional merupakan cerminan pluralisme hukum dan regulatory compliance sangat dibutuhkan dalam upaya percepatan penanganan Covid19 di Bali.

\section{DAFTAR PUSATAKA}

Agung Putu Wiwik S, L. J. (2020). Penanggulangan Covis-19 Berbasis Desa Adat Dalam Perspektif
Perlindungan Hukum Terhadp Aparatur Desa Adat. Prosiding Seminar Nasional Webinar Nasional Universitas Mahasaraswati Denpasar "Percepatan Penanganan COVID-19 Berbasis Adat Di Indonesia, " 71-76.

Atu Dewi, A. A. I. A. (2014). Eksistensi Otonomi Desa Pakraman Dalam Perspektif Pluralisme Hukum. Jurnal Magister Hukum Udayana (Udayana Master Law Journal), 3(3), 515-528. https://doi.org/10.24843/jmhu.2014.v03 .i03.p13

Dewi, A. A. I. A. A., Pramana, I. G. P., \& Tanaya, P. E. (n.d.). Hukum Adat Dan Hukum Nasional: Elaborasi Dalam Penyelenggaraan Pemerintah Daerah Mewujudkan Kesejahteraan Masyarakat. Www. Mpr. Go. Id, 115.

Dwijayanthi, P. T., Jones, K., \& Satyawati, N. G. A. D. (2017). Indigenous People, Economic Development and Sustainable Tourism: A Comparative Analysis between Bali, Indonesia and Australia. Udayana Journal of Law and Culture, $1(1), 16$. https://doi.org/10.24843/ujlc.2017.v01.i 01.p02

Franz von benda Beckman, Keebet Von Benda Beckmann, J. K. (2001). Jaminan Sosial, Sumber Daya Alam dan Kompleksitas Hukum. In Sumber Daya Alam dan Jaminan Sosial (p. 29). Pustaka Pelajar.

Griffiths, J. (1986). What is legal pluralism? Journal of Legal Pluralism and Unofficial Law, 18(24), 1-55. https://doi.org/10.1080/07329113.1986. 10756387

Irianto, S. (2003). Pluralisme Hukum Dan Masyarakat Saat Krisis. In Hukum dan kemajemukan budaya: sumbangan karangan untuk menyambut hari ulang tahun ke-70 Prof. Dr. T.O Ihromi. Yayasan Obor Indonesia. 
Irianto, S. (2009). Metode Penelitian Hukum Konstelaasi dan Refleksi. Jakarta: Yayasan Obor Indonesia.

Mandasari, Z. (2014). Politik Hukum Pengaturan Masyarakat Hukum Adat (Studi Putusan Mahkamah Konstitusi). Jurnal Hukum Ius Quia Iustum, 21(2), 227-250.

Mandira, I. M. C., \& Yudha, C. K. (n.d.). Peran Desa Adat Bali Dalam Melancarkan Kebijakan Penanggulangan Pandemi Covid-19. Journal Publicuho, 4(1), 1-18.

Marilang. (2017). Menimbang Paradigma Keadilan Hukum Progresif Considering The Progressive Legal Justice Paradigm. Jurnal Konstitusi, 14(2), 315-331. Retrieved from http://ejournal.mahkamahkonstitusi.go.i $\mathrm{d} /$ index.php/jk

Moore, S. F. (1973). Law and social change: the semi-autonomous social field as an appropriate subject of study. Law \& Society Review, 7(4), 719-746.

Mukminto, E., \& Marwan, A. (2019). Pluralisme Hukum Progresif: Memberi Ruang Keadilan Bagi Yang Liyan. Masalah-Masalah Hukum, 48(1), 13. https://doi.org/10.14710/mmh.48.1.201 9.13-24

Nurcholis, H. (2014). Undang-Undang Nomor 6 Tahun 2014 Tentang Desa Dilihat Dari Pasal 18 B Ayat 2 Uud 1945. Masalah-Masalah Hukum, 43(1), 149-159.

https://doi.org/10.14710/mmh.43.1.201 4.149-159

Nurfurqon, A. (2020). Analisis Kebijakan Pemerintah Daerah Dalam Penanganan Covid-19: Perspektif Hukum Administrasi Negara. Jurnal Yustika: Media Hukum Dan Keadilan, 23(01), 13-23.

https://doi.org/10.24123/yustika.v23i01. 2864

Nurjaya, I. N., \& SH, M. H. (2004).
Perkembangan Pemikiran Konsep Pluralisme Hukum. Dikutip Dari Http://Www. Huma. Co. Id, 12, 1-17.

Pasaribu, M. P. J., \& Sirait, N. N. (2018). Triangular concept of legal pluralism in the establishment of consumer protection law. E3S Web of Conferences, 52. https://doi.org/10.1051/e3sconf/201852 00032

Pramadita, I. (2017). Perjanjian Kerjasama Pengelolaan Pariwisata Tanah Lot Antara Pemerintah Daerah Kabupaten Tabanan Dengan Desa Pakraman Beraban Dalam Perspektif Keadilan dan Kepastian Hukum. Universitas Brawijaya.

Purnama, D. G. A. S. Y., \& Dewi, A. A. I. A. A. (n.d.). Desa adat Dalam Pengelolaan Tanah Adat Bali Berbasis Kebijakan Daerah. Acta Comitas: Jurnal Hukum Kenotariatan, 4(2), 343354.

Putri, K. A. M. P., Puspitasari, N. W. F., Dewi, N. K. K., Ekarini, N. W., Dewi, I. A. P. P., \& Mertadana, D. P. K. (2019). Pengaruh Hukum Adat Atau AwigAwig Terhadap Pengelolaan Dana Desa Di Desa Banjar Kecamatan Banjar Kabupaten Buleleng Provinsi Bali. Jurnal Ilmiah Akuntansi Dan Humanika, $\quad 8(1), \quad$ 1-13. https://doi.org/10.23887/jinah.v8i1.198 56

Rahman, I. N., Triningsih, A., \& Kurniawan, N. (2016). Dasar Pertimbangan Yuridis Kedudukan Hukum (Legal Standing) Kesatuan Masyarakat Hukum Adat dalam Proses Pengujian UndangUndang di Mahkamah .... Jurnal Konstitusi.

Sarawa, D. I., \& Mas' ud, A. (2020). Strategic public procurement regulatory compliance model with mediating effect of ethical behavior. Heliyon, 6(1), $\mathrm{e} 03132$. 
Sudantra, I. K. (2014). Pengaturan peradilan adat dalam awig-awig desa pakraman: Studi pendahuluan tentang eksistensi peradilan adat dalam kesatuan masyarakat hukum adat desa Pakraman. Jurnal Magister Hukum Udayana (Udayana Master Law Journal), 3(2).

Yulianingsih, W., \& CP, A. M. D. (2018). The Effectiveness of Awig-Awig as Customary Law in Balinese Culture (Case Study: The Coastal Areas and
Plains). Nusantara Science and Technology Proceedings, 91-97.

Yusa, I. G., \& Dharmawan, N. K. S. (2019). The Balinese Traditional Law Instrument: a Realism between the Balance of Cosmic and Human Rights Context. PADJADJARAN Jurnal Ilmu Hukum (Journal of Law), 5(3), 447463.

https://doi.org/10.22304/pjih.v5n3.a3 